Беликова К.М.

\title{
КОНСТРУИРОВАНИЕ СИСТЕМЫ ДОГОВОРНЫХ ОБЪЕДИНЕНИЙ, ЗАНЯТЫХ В ПРЕДПРИНИМАТЕЛЬСКОЙ ДЕЯТЕЛЬНОСТИ В СТРАНАХ БРИКС
}

\begin{abstract}
Аннотация: Предметом исследования в настоящей статье выступают корпоративные нормы стран БРИКС. Проблематика этого объединения в составе Бразилии, России, Индии, Китая и ЮАР привлекает в последнее время повышенное внимание экономистов, ученых, политиков. Однако предлагаемая статья содержит результаты решения принципиально иной задачи. Собрав и проанализировав современный научный материал и действующее корпоративное законодательство стран БРИКС в сфере деятельности договорных предпринимательских объединений, автор подробно рассматривает такие аспекты темы как функиионирование и порядок деятельности полных и коммандитных товарищества, а также партнерств в рассматриваемых странах. В работе используются общенаучные методы: системного анализа и обобщения нормативных и практических материалов, формальной и диалектической логики: анализ, синтез, индукиия, дедукиия, гипотезь, аналогии, и специальные методы юридико-правового исследования - сравнительно-правовой и историко-правовой, системного анализа и толкования правовых норм. Научная новизна исследования определяется тем, что данная работа, представляет собой, по существу первое всестороннее, системное и комплексное исследование проблем правового регулирования деятельности договорных форм ведения предпринимательской деятельности в странах БРИКС, проведенное на современном научном правовом материале, включая материаль правоприменительной практики.
\end{abstract}

Ключевые слова: БРИКС, Россия, Индия, ЮАР, Китай, Бразилия, договорные объединения, предпринимательство, товарищество, коммандитное товарищество.

Abstract: The subject of this research is the corporate laws of the BRICS countries. The problematics of this association in Brazil, Russia, India, China, and South Africa lately attracts a higher number of financial experts, scholars, and politicians. But this article contains results of a solution to a principally different issue. Having compiled and analyzed modern scientific material and current corporate legislation of the BRICS countries in the area of corporate contractual associations, the author carefully examines such aspects of the topic as the functionality and order of general and limited partnerships in the countries in question. The scientific novelty of this research is defined by the fact that this work in essence represents a first diverse, systemic and comprehensive research of the issues of legal regulation of the activities of contractual forms of business within the BRICS countries, conducted using modern scientific legal material, including materials from law enforcement.

Keywords: Contractual associations, Brazil, China, SAR, India, Russia, BRICS, business , partnership, limited partnership.

бсуждение правового регулирования форм предпринимательской деятельности в разных странах позволяет понять процессы унификации правового регулирования в рассматриваемой сфере. Предпринимательская деятельность преодолевает национальные границы, и ее организационно-правовые формы, принятые в одной стране, не должны препятствовать привлечению иностранного капитала и осуществлению предпринимательской деятельности в другой. Эта тенденция далеко не чужда странам БРИКС. Поэтому обратимся в настоящей статье к исследованию и изучению системы договорных объединений, занятых в предпринимательской деятельности в странах БРИКС. Они нередки в правовой реальности этих стран.
В Бразилии существуют такие организационноправовые формы предпринимательских (хозяйственных) товариществ (sociedade empresária - ст. 10391092 ГК Бразилии 2002 г. [1]), как полное (sociedade em Nome Coletivo) и коммандитное товарищества (sociedade em Comandita simples), а также негласное товарищество (sociedade em Conta de Participação ст. 991-996 ГК), и акционерная коммандита (sociedade em Comandita por Ações), - пример «смешанной», промежуточной коллективной формы ведения предпринимательской деятельности [2, с. 258, 259].

Бразильский законодатель определяет "sociedade em Nome Coletivo”, как товарищество, участники которого несут солидарную и субсидиарную ответственность по обязательствам товарищества (ст. 1039 ГК). 
Согласно положению Гражданского кодекса Бразилии 2002 г. участниками полного товарищества могут быть только физические лица. Кроме того, участники в специальном соглашении или учредительном договоре вправе ограничить ответственность каждого из них (ст. 1039). Непосредственное руководство компанией осуществляют участники товарищества, действуя в соответствии с полномочиями согласно учредительному договору.

Коммандитное товарищество (sociedade em Comandita Simples) в соответствии с бразильским законодательством также предполагает участие лиц в качестве участника с неограниченной ответственностью, а также - коммандитиста, отвечающего по обязательствам в пределах суммы вклада. Права коммандитистов ограничены: они вправе участвовать на собраниях товарищества, контролировать финансовые операции, но не могут представлять товарищество в отношениях с третьими лицами (ст. 1045-1051 ГК).

Негласное товарищество (sociedade em Conta de Participação - ст. 991-996 ГК) предполагает существование двух видов участников: собственника предприятия (коммерсант или товарищество) и негласного товарища (вкладчика). Негласный товарищ обязан внести предусмотренный договором капитал и, соответственно, несет риск убытков в пределах размера внесенной доли, и имеет право на прибыль. «Такой коммерсант или товарищество действует в отношении третьих лиц так, как если бы имущество было их собственным (de propiedad del asociante), что обусловливает отсутствие каких-либо отношений между третьими лицами и негласным участником» [3, c. 280, 281]. Иными словами, для третьих лиц негласный участник юридически не существует. Негласный товарищ вправе знакомиться со всей документацией о деятельности товарищества, но участвовать в его управлении не может.

Коммандитное товарищество на акциях (sociedade em Comandita por Ações - ст. 1090 - 1092 ГК) является сочетанием коммандитного товарищества и акционерного общества. Во-первых, капитал товарищества разделен на акции, во-вторых, имеет место участие полных товарищей, отвечающих неограниченно и солидарно по обязательствам товарищества, и коммандитистов, к которым не могут быть предъявлены никакие требования кредиторов акционерной коммандиты. Кроме того, согласно положению закона, бывший руководитель акционерной коммандиты отвечает по обязательствам, возникшим под его управлением, в течение двух лет после выбытия из товарищества (ст. 1091 ГК). Дела товарищества ведут полные товарищи, коммандитисты вправе участвовать в общем собрании акционеров. Общее собрание не вправе принимать решения по вопросам, касающимся изменения учредительных документов, увеличения или уменьшения размера уставного капитала, выпуска акций и облигаций без согласия правления товарищества.

Все предпринимательские (хозяйственные) товарищества в Бразилии подлежат регистрации и занесению в Государственный реестр торговых товариществ (Registro Público de Empresas Mercantis), регистрация вступает в силу только с момента выдачи соответствующих документов [4], а товарищества (sociedade) после этого приобретают статус юридического лица (ст. 985 ГК Бразилии 2002 г.). Поскольку в Бразилии преобладает нормативно-явочный способ создания юридических лиц, документы, необходимые для регистрации, должны быть предоставлены в течение 30 дней со дня принятия решения о создании предпринимательского товарищества. Сведения из регистрационного реестра могут быть истребованы любым заинтересованным лицом в соответствии с установленной процедурой. В случае отказа в регистрации законодатель возлагает ответственность за это на лиц, подавших документы. Также важно отметить роль суда в процессе регистрации. Суд уполномочил регистрационный орган проверять регулярность публикации определенных правовых изданий, на регистрирующем органе также лежит обязанность по проверке и контролю за соответствие представленных документов требованиям законодательства.

Гражданский кодекс Бразилии 2002 г. определяет, что руководство товариществом осуществляется исключительно его участниками. Решения принимаются большинством голосов при условии присутствия участников, обладающих более, чем половиной складочного капитала. Ведение дел товарищества может быть доверено одному или нескольким участникам. По общему правилу каждый участник вправе совершать любые сделки с третьими лицами, которые порождают и соответствующие обязанности для товарищества. Однако такая сделка может быть признана недействительной ввиду отсутствия полномочий у лица, в случае указания таких ограничений в учредительном договоре товарищества или если будет доказано, что третье лицо знало об ограничениях [5]. Если управление делами товарищества осуществляется несколькими лицами, то в случае нарушения своих обязанностей они несут солидарную ответственность по возмещению ущерба. Полномочия руководителей могут быть прекращены по решению суда. Кроме того, участники товарищества вправе оспорить действия уполномоченных лиц на ведение дел товарищества. В 
этом случае уполномоченное лицо должно возместить ущерб, нанесенный товариществу в результате его неправомерных действий.

В отношении коммандитного товарищества применяются вышеприведенные правила, регулирующие порядок деятельности органов полного товарищества. Вкладчики не участвуют в управлении товариществом и не вправе заключать сделки от его имени. В случае совершения подобных сделок, вкладчик несет ответственность, равную по объему с ответственностью полных товарищей.

Управление в коммандитном товариществе на акциях осуществляется полными товарищами, которые выполняют функции правления в акционерном обществе. Акционеры обладают правом на участие в управлении хозяйственной деятельностью товарищества, отвечая при этом неограниченно и солидарно по соответствующим обязательствам. Учредительный договор определяет полномочия руководителя (директора - diretor) товарищества, он может быть отстранен от должности только по решению акционеров, обладающих не менее, чем $2 / 3$ акций. При этом отстраненный руководитель еще в течение двух лет отвечает по обязательствам товарищества, возникшим под его управлением. Общее собрание акционеров не вправе без согласия исполнительного органа принимать решения по вопросам изменения предмета деятельности товарищества, увеличения или уменьшения уставного капитала, выпуска облигаций или акций.

В негласном товариществе структура управления достаточно проста, поскольку делами управляет только гласный товарищ (sócio ostensivo). Негласный товарищ (sócio participante) не участвует в управлении. Ведь в отношениях с третьими лицами он выступать не вправе.

Российское право определяет товарищества, как объединения лиц, а общества, - как объединения капиталов. Как отмечалось выше хозяйственными товариществами и обществами признаются корпоративные коммерческие организации (п. 1 ст. 66 ГК РФ [6]). Хозяйственные товарищества согласно ГК РФ, могут создаваться либо в форме полного товарищества, либо товарищества на вере (коммандитного товарищества) [7, с. 145-175]. Существенное отличие от обществ заключается в непосредственно личном участии в делах товарищества, а также доверительном характере отношений между участниками. В связи с этим товарищества иначе именуют «персональными товариществами». Хотя в российском правопорядке они признаются юридическими лицами, мы рассматриваем их здесь, и одной из причин является то, что в основе их функционирования лежит учредительный договор (абз. 2 п. 1 ст. 52 ГК РФ).

Согласно положениям ГК РФ о хозяйственных товариществах: полное товарищество - это «товарищество, участники которого (полные товарищи) в соответствии с заключенным между ними договором занимаются предпринимательской деятельностью от имени товарищества и несут ответственность по его обязательствам принадлежащим им имуществом» (п. 1 ст. 69). Как отмечалось выше Кодекс все коммерческие организации наделяет общей правоспособностью, и полное товарищество не является исключением. Оно выступает в имущественном обороте от своего имени, приобретает права и принимает на себя обязательства.

Для создания товарищества необходимо существование как минимум двух участников. Вопрос о том, какие субъекты могут быть участниками хозяйственных товариществ и обществ, оговаривается в п. 5 и 6 ст. 66.1 ГК РФ. Так, участниками полных товариществ и полными товарищами в товариществах на вере могут быть индивидуальные предприниматели и коммерческие организации. Законом может быть запрещено или ограничено участие отдельных категорий лиц в хозяйственных товариществах и обществах. Так, применительно к полным товариществам это положение находит отражение в том, что лицо может быть участником лишь одного полного товарищества. Это положение представляется оправданным, поскольку существенной чертой полного товарищества является неограниченная солидарная ответственность участников по обязательствам товарищества всем своим имуществом [8, с. 270]. С одной стороны, очевиден повышенный риск для участника, с другой стороны, - весомая гарантия для кредиторов. Однако личная ответственность участника наступает лишь в субсидиарном порядке, то есть при отсутствии имущества у самого товарищества (п. 1 ст. 75 ГК РФ). Если у участника отсутствует личное имущество, кредиторы для покрытия его собственных долгов вправе обратить взыскание на его долю в складочном капитале полного товарищества. В соответствии с законодательством в данном случае его членство в полном товариществе прекращается (ст. 80 ГК РФ). Хозяйственные товарищества и общества могут быть учредителями (участниками) других хозяйственных товариществ и обществ, за исключением случаев, предусмотренных законом.

Полное товарищество, будучи хозяйственным товариществом, действует на основании учредительного договора, который заключается его учредителями (участниками) и к которому применяются правила 
Гражданского кодекса об уставе юридического лица (абз. 2 п. 1 ст. 52 ГК РФ).

Учредительный договор полного товарищества должен содержать сведения о фирменном наименовании и месте нахождения товарищества, условия о размере и составе его складочного капитала; о размере и порядке изменения долей каждого из участников в складочном капитале; о размере, составе, сроках и порядке внесения ими вкладов; об ответственности участников за нарушение обязанностей по внесению вкладов (п. 2 ст. 70 ГК РФ).

Учредители (участники) полного товарищества, как и любого другого юридического лица, вправе утвердить внутренний регламент и иные внутренние документы юридического лица, регулирующие корпоративные отношения (пункт 1 статьи 2) и не являющиеся учредительными документами, но содержащие положения, не противоречащие учредительному договору юридического лица (п. 5 ст. 52 ГК РФ).

Юридическое лицо подлежит государственной регистрации в уполномоченном государственном органе, а данные государственной регистрации включаются в единый государственный реестр юридических лиц, открытый для всеобщего ознакомления. Именно с момента государственной регистрации договора и создается полное товарищество, а данные о нем считаются включенными в единый государственный реестр юридических лиц со дня внесения соответствующей записи в этот реестр (п. 1, 2, 8 ст. 51 ГК РФ).

Новеллой ГК РФ является то, что юридическое лицо может быть создано на основании решения учредителя (учредителей) об учреждении юридического лица. В решении об учреждении корпоративного юридического лица (статья 65.1), в том числе полного товарищества, указываются также сведения о результатах голосования учредителей по вопросам учреждения юридического лица, о порядке совместной деятельности учредителей по созданию юридического лица. (п. 1 и 3 ст. 50.1 ГК РФ). Такое решение выступает, на наш взгляд, предпосылкой и предшествующим государственной регистрации этапом, который может и не выступать в качестве обязательного.

В фирменном наименовании полного товарищества законодатель требует указания либо имен всех участников и слова «полное товарищество», либо имени одного или нескольких участников с добавлением слов «и компания» или «полное товарищество» (п. 3 ст. 69 ГК РФ). Данное требование вполне обосновано ввиду специфики ответственности. Таким образом, кредиторы и третьи лица смогут оценить платежеспособность товарищества, принимая во внимание, например, состоятельность отдельных участников.
Учредительным договором может быть предусмотрено, что управление делами товарищества поручено отдельным его членам, или же осуществляется совместно всеми участниками. В остальных случаях каждый участник полного товарищества вправе действовать от имени товарищества (п. 1 ст. 72 ГК РФ). Сделки, заключенные любым из участников от имени товарищества, считаются действительными, поскольку, презюмируется, что каждый полный товарищ обладает такими полномочиями, если товарищество не докажет, что третье лицо заведомо знало или должно было знать о существовавших ограничениях. Эти положения основываются на более общих положениях п. 1 ст. 53 ГК РФ, закрепляющей, что учредительным документом может быть предусмотрена возможность предоставления полномочий выступать от имени юридического лица нескольким лицам, действующим совместно или независимо друг от друга. Сведения об этом подлежат включению в единый государственный реестр юридических лиц.

Об ответственности лица, уполномоченного выступать от имени юридического лица, говорится в ст. 53.1 ГК РФ, так: лицо, которое в силу закона, иного правового акта или учредительного документа юридического лица уполномочено выступать от его имени, обязано возместить по требованию юридического лица, его учредителей (участников), выступающих в интересах юридического лица, убытки, причиненные по его вине юридическому лицу (п. 1 ст. 53.1 ГК РФ).

Участник полного товарищества обязан участвовать в его деятельности в соответствии с условиями учредительного договора. Он не вправе без согласия остальных участников совершать от своего имени в своих интересах или в интересах третьих лиц сделки, однородные с теми, которые составляют предмет деятельности товарищества (п. 1 и 3 ст. 73 ГК РФ). Санкция за нарушение данного предписания включает либо возмещение убытков товариществу, либо передачу последнему всей прибыли от такой сделки. Стоит отметить, что и права, и обязанности участников полных товариществ нужно понимать в контексте прав и обязанностей участников корпорации, закрепляемых положениями ст. 65.2 ГК РФ.

Решения в полном товариществе принимаются по общему согласию всех участников. Однако в учредительном договоре участники вправе определить, что решения принимаются большинством голосов (п. 1 ст. 71 ГК РФ). При этом закон устанавливает права участников на защиту своих имущественных интересов против произвола и злоупотребления полномочиями назначенными лицами. Так, в случае «грубого нарушения уполномоченным лицом своих 
обязанностей или обнаружившейся неспособности его к разумному ведению дел» полномочия лица на ведение дел по судебному решению прекращаются (п. 2 ст. 72 ГК РФ).

Каждый участник товарищества независимо от того, уполномочен ли он вести дела товарищества, вправе получать всю информацию о деятельности товарищества и знакомиться со всей документацией по ведению дел. Отказ от этого права или его ограничение, в том числе по соглашению участников товарищества, ничтожны (п. 3 ст. 71 ГК РФ).

Участник полного товарищества обязан внести не менее половины своего вклада в складочный капитал товарищества до его государственной регистрации. Остальная часть должна быть внесена участником в сроки, установленные учредительным договором. В случае невнесения всей части вклада, участник обязан уплатить товариществу 10\% годовых с невнесенной части вклада и возместить причиненные убытки (п. 2 ст. 73 ГК РФ).

Участник также вправе выйти из товарищества, предупредив об этом не менее, чем за 6 месяцев до фактического выхода (ст. 77 ГК РФ). При этом он вправе получить обратно часть имущества, равную его доле в складочном капитале. Но в течение 2-х лет выбывший участник отвечает по обязательствам товарищества, возникшим до момента его выбытия.

Полные товарищи не обладают правом преимущественной покупки в случае передачи доли третьему лицу или другому участнику товарищества. Необходимо лишь согласие всех участников на совершение подобной сделки, если же такое согласие отсутствует, то участник вправе выйти из товарищества (ст. 78, 79 ГК РФ).

Полное товарищество ликвидируется в случае выбытия или смерти одного из участников, признания его безвестно отсутствующим, недееспособным или ограниченно дееспособным, если учредительным договором не предусмотрено, что товарищество продолжает свою деятельность. Также полное товарищество подлежит ликвидации, если остается один единственный участник. Однако единственный участник вправе принять решение о преобразовании товарищества в хозяйственное общество (ст. 81 ГК РФ).

Под товариществом на вере понимается товарищество, в котором наряду с участниками, осуществляющими от имени товарищества предпринимательскую деятельность и отвечающими по обязательствам товарищества своим имуществом (полными товарищами), имеется один или несколько участников - вкладчиков (коммандитистов), которые несут риск убытков, связанных с деятельностью това- рищества, в пределах сумм внесенных ими вкладов и не принимают участия в осуществлении участниками предпринимательской деятельности (п. 1 ст. 82 ГК РФ). Иными словами, коммандита это такое объединение лиц, в котором хотя бы один участник отвечает по общим долгам всем имуществом, а другой (или другие) рискует только своим вкладом [8, с. 274, 279280.]. В фирменном наименовании товарищества на вере необходимо указать имена всех, нескольких или одного полного товарища со словами «и компания, товарищество на вере (или коммандитное товарищество)» (п. 4 ст. 82 ГК РФ).

Поскольку товарищество на вере также, как и полное товарищество, является договорным объединением, то необходимо наличие минимум 2-х участников: одного полного товарища и одного вкладчика, правовой статус которого подтверждается специальным «свидетельством об участии». Вкладчиками в товариществах на вере (как и участниками хозяйственных обществ) могут быть: граждане и юридические лица, а также публично-правовые образования (прядок участия Российской Федерации, субъектов Российской Федерации, муниципальных образований в отношениях, регулируемых гражданским законодательством, устанавливаемый положениями ст. 125 ГК РФ, остался без изменений), а также учреждения, - с разрешения собственника имущества учреждения, если иное не установлено законом. При этом согласно п. 6 ст. 66.1 ГК РФ государственные органы и органы местного самоуправления не вправе участвовать от своего имени в хозяйственных товариществах (и обществах). При этом лицо может быть полным товарищем только в одном товариществе на вере. Единственным полным товарищем в коммандитном и полном товариществах может стать и юридическое лицо (обычно общество с ограниченной ответственностью). Участник полного товарищества не может быть полным товарищем в товариществе на вере. Полный товарищ в товариществе на вере не может быть участником полного товарищества. Число коммандитистов в товариществе на вере согласно последним изменениям в ГК не должно превышать 20-ти. В противном случае оно подлежит преобразованию в хозяйственное общество в течение года, а по истечении этого срока - ликвидации в судебном порядке, если число его коммандитистов не уменьшится до указанного предела (п. 3 ст. 82 ГК РФ).

Товарищество на вере создается и действует на основании учредительного договора, который подписывается всеми полными товарищами. Он должен содержать сведения о фирменном наименовании и месте нахождения товарищества, о совокупном размере вкладов, вносимых вкладчиками и др. (ст. 83 ГК 
РФ). Коммандитисты (вкладчики) не подписывают учредительный договор, они заключают договор с товариществом о внесении ими вкладов.

Правовой статус вкладчика имеет и иные отличия от статуса полного товарища. Так, управление и ведение дел в коммандитных товариществах осуществляется полными товарищами по правилам, предусмотренным ГК о полном товариществе. Коммандитисты, таким образом, не вправе участвовать в управлении делами товарищества и совершать сделки с третьими лицами (ст. 84 ГК РФ). На совершение указанных действий необходимо получить доверенность [9, с. 300-302]. При этом вкладчики не вправе оспаривать решения полных товарищей относительно управления товарищества. Если же коммандитист вступает в деловые отношения с третьими лицами от имени товарищества на вере, и третьи лица имеют основания предполагать, что заключают сделку с обычным товарищем, то участник с ограниченной ответственностью будет отвечать по всем вытекающим обязательствам неограниченно и солидарно с полными товарищами. Кроме того, полные товарищи отвечают по обязательствам товарищества солидарно и субсидиарно, а вкладчики несут ответственность лишь в пределах суммы внесенных ими вкладов. Коммандитист получает прибыль пропорционально размеру своего вклада. В случае передачи вкладчиком своей доли третьему лицу в отличие от полных товарищей ему не требуется согласие полного товарищества. При этом другие вкладчики обладают правом преимущественной покупки передаваемой доли. Одновременно, если в фирменное наименование будет включено имя вкладчика, то он автоматически приобретает статус полного товарища и несет, соответственно, неограниченную и солидарную ответственность по долгам товарищества.

При выбытии всех вкладчиков товарищество на вере подлежит ликвидации, если не будет преобразовано в полное товарищество. При ликвидации товарищества вкладчики имеют преимущественное перед полными товарищами право на получение своих вкладов из имущества товарищества, оставшегося после удовлетворения требований кредиторов. После чего вместе с полными товарищами участвуют в распределении имущества пропорционально вкладам (п. 2 ст. 86 ГК РФ) [10].

Изменения, внесенные в ГК РФ, коснулись и положений о реорганизации, которые являются общими для всех юридических лиц, включая и товарищества, и общества. Так, реорганизация юридических лиц может осуществляться в форме слияния, присоединения, разделения, выделения, преобразования (п. 1 ст. 57 ГК РФ). При слиянии два и более юридических лица прекращают свое существование и возникает новое, к которому и переходят их права и обязанности в соответствии с передаточным актом. Присоединение представляет собой реорганизацию, при которой одно юридическое лицо прекращает свое существование и вливается в состав другого, к которому переходят все права и обязанности. В случае разделения одно юридическое лицо прекращает свое существование и на его месте возникает два юридических лица. Выделение имеет место в случае, когда из состава одного юридического лица выделяются одно и более юридическое лицо, а прежнее не прекращает свое существование. При этом права и обязанности этого юридического лица переходят к вновь возникшим юридическим лицам в соответствии с передаточным актом, а не разделительным балансом, как было согласно ранее действовавшем редакции ГК (п. 3 ст. 58 ГК РФ). В последних двух случаях, в случаях, установленных законом, реорганизация юридического лица осуществляется по решению уполномоченных государственных органов или по решению суда (п. 2 ст. 57 ГК РФ). При преобразовании речь идет об изменении организационноправовой формы юридического лица, к которому переходят все права и обязанности в соответствии с передаточным актом.

Согласно последим изменениям в ГК допускается реорганизация юридического лица с одновременным сочетанием различных ее форм, названных выше, а также с участием двух и более юридических лиц, в том числе созданных в разных организационно-правовых формах, если ГК или другим законом предусмотрена возможность преобразования юридического лица одной из таких организационно-правовых форм в юридическое лицо другой из таких организационноправовых форм (абз. 2 и 3 п. 1 ст. 57 ГК РФ).

Юридическое лицо считается реорганизованным, за исключением случаев реорганизации в форме присоединения, с момента государственной регистрации юридических лиц, создаваемых в результате реорганизации. При реорганизации юридического лица в форме присоединения к нему другого юридического лица первое из них считается реорганизованным с момента внесения в единый государственный реестр юридических лиц записи о прекращении деятельности присоединенного юридического лица При этом государственная регистрация юридического лица, создаваемого в результате реорганизации (в случае регистрации нескольких юридических лиц первого по времени государственной регистрации), 
допускается не ранее истечения соответствующего срока для обжалования решения о реорганизации (п. 4 ст. 57 ГК РФ).

ГК предусматривает гарантии прав кредиторов реорганизуемого юридического лица (ст. 60 ГК РФ), а также говорит о последствиях признания недействительным решения о реорганизации юридического лица (ст. 60.1 ГК РФ) и признании реорганизации корпорации несостоявшейся (ст. 60.2 ГК РФ). Последние две статьи являются новыми: ранее ГК таких механизмов не предусматривал. Вопросы правопреемства при реорганизации юридических лиц немного по-новому регулируются положениями ст. 58 ГК РФ.

В Индии действуют Закон о партнерствах 1932 г. [11] и Закон о партнерствах с ограниченной ответственностью 2009 г. [12] Согласно положениям указанных законов, в Индии существуют партнерства с неограниченной и с ограниченной ответственностью.

Партнерство с неограниченной ответственностью (partnership) согласно Закону 1932 г. не является юридическим лицом, но подлежит регистрации и занесению в соответствующий реестр. Правовым основанием для деятельности партнерств по Закону 1932 г. является учредительный договор. Партнерство считается созданным на бессрочный период, если в договоре не установлено иное.

Государственную регистрацию таких партнерств, не обладающих статусом юридического лица, осуществляют учредители путем отправки по почте или явки в регистрирующий орган соответствующего региона по месту ведения хозяйственной деятельности партнерства с заявлением о регистрации, квитанцией об оплате государственной пошлины и заверенной копией учредительного договора партнерства.

Учредительный договор должен включать следующие сведения: фирменное наименование; указание на характер деятельности партнерства; место нахождения или место основной деятельности; дату присоединения к работе партнерства каждого участника; имена и фамилии, место постоянного проживания каждого партнера; срок, на который создано партнерство (ст. 58 Закона 1932 г.). Учредительный договор должен быть подписан всеми участниками или их представителями, полномочными на совершение таких действий.

Заявление о регистрации партнерства должно быть направлено в регистрирующий орган в течение года со дня создания партнерства. В случае соблюдения всех предписаний законодательства, регистрирующий орган вносит соответствующую запись в реестр компаний, с момента которого партнерство считается созданным. Фирменное наименование при этом должно помимо имен всех участников партнерства содержать в скобках сразу после наименования слово - «зарегистрированное».

Участники (партнеры), осуществляющие управление партнерством, обязаны предоставлять всю информацию о деятельности каждому партнеру или его представителю. В случае, если партнер заключает сделки от своего имени и в своих интересах и, таким образом, причиняет вред фирме, то он обязан возместить причиненные убытки. В учредительном договоре может быть предусмотрено, что участник не вправе заниматься иной предпринимательской деятельностью, являясь участником данной фирмы. Если же партнер ведет подобный бизнес, то он должен выплатить фирме всю прибыль, полученную в ходе такой деятельности (ст. 16 Закона 1932 г.).

Партнерство с ограниченной ответственностью (далее - LLP) согласно Закону 2009 г. является юридическим лицом и подлежит занесению в Государственный реестр. Участниками партнерства могут быть как физические, так и юридические лица. Как минимум два участника партнерства должны быть назначены в качестве агентов фирмы в соответствии с учредительным договором, один из которых должен быть резидентом Индии (Resident in India). “Resident in India" - это, согласно положениям раздела 7 Закона, лицо, которое находится на территории Индии в течение не менее 182 дней за прошедший год. Если такой агент не назначен или существует только один агент, то каждый из партнеров считается агентом фирмы. Агент фирмы несет ответственность за все действия партнерства, в том числе за подачу, возврат документов, заявлений в соответствии с Законом и учредительным договором. В случае нарушений указанных положений, с агента взыскиваются все штрафы, налагаемые на LLP. За нарушение положений об агентах на партнерство и каждого участника налагается штраф в размере не менее 10 тысяч рупий [13].

Партнер LLP не отвечает по договорным обязательствам партнерства, а также не несет ответственности за противоправные действия других партнеров.

В качестве вклада участник может предложить движимое или недвижимое имущество, материальные или нематериальные блага, имущественные права, в том числе деньги, векселя, договоры об оказании услуг.

Учредительный договор должен соответствовать всем требованиям законодательства штата, где находится и осуществляет хозяйственную деятельность партнерство. В регистрирующий орган подается заявление, составленное адвокатом, юристом или иным уполномоченным на это лицом. 
Учредительный договор должен содержать фирменное наименование партнерства, предмет деятельности, место нахождения, имена и места проживания его учредителей. Кроме того, закон предусматривает санкцию за указание ложных сведений до двух лет лишения свободы и штраф в размере 10 тыс. рупий [14]. В течение 14 дней регистрирующий орган принимает решение о регистрации. В случае положительного решения производится соответствующая запись в реестре и выдается сертификат об инкорпорации. С момента выдачи Сертификата партнерство считается созданным.

Фирменное наименование должно включать словосочетание «с ограниченной ответственностью» или аббревиатуру «LLP». Важно отметить, что согласно положениям рассматриваемого Закона, партнерства вправе обратиться с заявкой в регистрирующий орган о резервировании фирменного наименования: предполагаемого наименования партнерства или нового наименования вместо предыдущего (ст. 16 Закона 1932 г.). В случае соответствия данного наименования требованиям законодательства, регистрирующий орган вправе зарезервировать фирменное наименование на не более, чем три месяца с момента подачи заявки.

В Индии в партнерствах с неограниченной ответственностью право участия в управлении делами партнерства предоставляется каждому партнеру. Решения принимаются простым большинством голосов. Однако решения относительно изменения предмета деятельности партнерства или вопросов, кардинально меняющих саму природу партнерства, должны приниматься единогласно.

Партнер, управляющий делами, не вправе получать вознаграждение за свою деятельность, но несет ответственность за умышленное пренебрежение своими обязанностями.

В соответствии с положениями ст. 19 Закона участник, выступающий в качестве агента фирмы, обладает подразумеваемыми полномочиями (implied authority). Доктрина подразумеваемых полномочий характерна для Индии, как страны, воспринявшей традиции общей системы права [15]. «Таковыми считаются, например, полномочия агента действовать в соответствии с разумными обычаями и торговыми обыкновениями того рынка или биржи, где он был нанят» [16, с. 214]. Однако, подразумеваемые полномочия не наделяют его правом представлять фирму при рассмотрении споров в арбитраже, открывать банковский счет на свое имя для деятельности партнерства, отзывать иск, поданный от имени фирмы, приобретать недвижимое имущество от имени фирмы (ст. 19 Закона 1932 г.). Если агент совершил сделку, выходящую за рамки подразумеваемых полномочий, то партнерство не вправе оспорить такую сделку, «если только не докажет, что третье лицо знало об отсутствии надлежащих полномочий у нарушителя» [16, с. 215]. Все партнеры несут солидарную и субсидиарную ответственность по обязательствам фирмы.

Закон 2009 г. о партнерствах с ограниченной ответственностью гласит, что каждый участник вправе выступать в качестве агента партнерства. Ответственность партнерства за действия участника не наступает, если он не обладал полномочиями на совершение действий, и третье лицо заведомо знало об этом. В данном случае он несет неограниченную ответственность по обязательствам, возникшим из этой сделки. То есть в данном случае индийский законодатель также придерживается доктрины подразумеваемых полномочий. Во всех остальных случаях партнерство несет ответственность за все неправомерные действия или бездействия своего участника. По возникшим обязательствам партнерство отвечает только своим имуществом.

Закон о партнерствах 1932 г. предусматривает добровольный и принудительный порядок ликвидации партнерства с неограниченной ответственностью. Так, ликвидация может проводиться, например, при наступлении непредвиденных обстоятельств, включая смерть одного из участников или признание его неплатежеспособным по решению суда и пр. Если же срок деятельности партнерства не определен в учредительном договоре, любой участник вправе направить другим участникам уведомление о его намерении распустить партнерство. Партнерство подлежит роспуску со дня получения участниками уведомления. Из имущества партнерства осуществляется удовлетворение требований кредиторов [17]. Оставшееся имущество распределяется между его участниками. После ликвидации партнерства участники обладают полномочиями по управлению делами для завершения всех дел, а также несут ответственность по обязательствам партнерства перед третьими лицами за любое действие, совершенное тем или иным участником до роспуска партнерства.

Что касается ликвидации партнерства с ограниченной ответственностью, закон 2009 г. также предусматривает добровольный и принудительный порядок ликвидации. Основаниями для осуществления принудительной процедуры ликвидации: если в течение менее, чем шести месяцев количество участников партнерства снижается до двух; если партнерство не в состоянии платить по своим долгам; если деятельность партнерства была направлена против общественного и государственного порядка Индии и др. 
В $\boldsymbol{K H P}$ Закон КНР «О партнерствах» 1997 г. [18] предусматривает функционирование договорных хозяйствующих субъектов в двух формах партнерства (partnership): общие/полные (general) / обычные (common) и с ограниченной ответственностью (commanditarian/limited liability - ст. 2 Закона 1997 г.) [19]. Различия в приведенных названиях обусловлены переводами китайских законов на английский язык авторами с применением различной лексики.

Китайский законодатель прямо не относит партнерства к юридическим лицам, что следует из положений ст. 6 Закона 1997 г., согласно которым уплата налогов осуществляется его участниками. Последние по отдельности выплачивают налог на доходы согласно соответствующим государственным положениям, касающимся налогов, в отношении дохода от хозяйственной деятельности и иного дохода партнерства. Закон, однако, предусматривает обязанность регистрации и занесения партнерства в реестр.

Чтобы зарегистрировать партнерство в КНР необходимо обратиться в соответствующий государственный орган с заявлением о регистрации, учредительным договором, удостоверениями личности учредителей и иными требуемыми законом документами (ст. 9 Закона 1997 г.). В течение 20 дней с момента принятия заявления регистрирующий орган должен принять решение о регистрации партнерства. Внесенные изменения в регистрационные документы партнерства необходимо также зарегистрировать в течение 15 дней. С момента выдачи регистрирующим органом Свидетельства о праве хозяйственной деятельности партнерство считается созданным. Только через один день после регистрации юридическому лицу выдается документ, подтверждающий государственную регистрацию.

Согласно Закону КНР 1997 г. участники обычного (общего, полного) партнерства несут неограниченную солидарную ответственность по обязательствам партнерства. Партнерства с ограниченной ответственностью, в свою очередь, состоят из обычных участников, несущих неограниченную солидарную ответственность, и участников с ограниченной ответственностью, отвечающих по обязательствам партнерства в пределах суммы вклада (ст. 2 Закона КНР 1997 г.).

Участниками партнерств могут выступать как физические, так и юридические лица. Государственные предприятия, ценные бумаги которых допущены к биржевым торгам, и общественные организации не могут являться участниками общих партнерств и простыми участниками партнерств с ограниченной ответственностью. Основным учредительным документом партнерств, как и в рассмотренных выше странах, является учредительный договор между его партнерами (ст. 4 Закона КНР 1997 г.).

Однако важно отметить, что учредительный документ должен содержать сведения о сфере деятельности и цели создания партнерства. Место нахождения юридического лица определяется по основному месту ведения хозяйственной деятельности. Учредительный договор вступает в силу с момента заверения подписями и печатями всех участников партнерства (ст. 18, 19 Закона 1997 г.).

Отличительных особенностей в отношении фирменного наименования партнерства рассматриваемый закон не устанавливает. Оно должно содержать соответственно наименование и указание на вид партнерства: «general partnership» или «commanditarian partnership».

Закон утверждает закрытый перечень сведений, которые необходимо внести в учредительный договор. К ним относят: наименование партнерства; имена и фамилии (или наименования) участников и место их проживания (нахождения); способы, суммы и сроки внесения вкладов; порядок распределения прибыли и убытков; осуществления управления партнерством; вступление и выход из партнерства; ответственность при нарушении обязательств по договору (ст. 18 Закона 1997 г.).

В качестве вкладов партнеров общего партнерства могут быть использованы денежные средства, материальные ценности, права интеллектуальной собственности, права пользования землей или иные виды имущественных прав, а также трудовые услуги (ст. 16 Закон 1997 г.).

Партнеры пользуются равными правами по управлению деятельностью общего партнерства, т.е. вправе совместно осуществлять управление делами партнерства, вправе контролировать деятельность партнерства и знакомиться со всей информацией, касающейся деятельности партнерства.

В качестве представителей партнерства возможно назначение одного или нескольких участников и ответственных за управление делами. При раздельном управлении деятельностью общего партнерства управляющие партнеры могут оспаривать действия остальных его партнеров и требовать аннулирования поручения на управление деятельностью партнерства.

При подаче протеста выполнение соответствующего действия приостанавливается (ст. 29 Закона 1997 г.). Такие участники вправе обратиться с заявлением в суд о прекращении участником полномочий на ведение дел партнерства, в случае «грубого нарушения уполномоченным лицом своих обязанностей или обнаружившейся неспособности его к разумному ведению дел» [19]. 
Доход, полученный при управлении делами партнерства управляющим участником, принадлежит партнерству (ст. 29 Закона 1997 г.). В случае причинения ущерба партнерству вследствие превышения пределов своей компетенции, умышленных действий, руководители партнерства несут ответственность в виде обязанности по компенсации нанесенного партнерству ущерба.

Управление деятельностью партнерств с ограниченной ответственностью осуществляют обычные участники партнерства. Закон также устанавливает право управляющего партнерством на получение вознаграждения, что необходимо указать в учредительном договоре. Участники с неограниченной ответственностью не участвуют в управлении делами партнерства, но обладают некоторыми правами в отличие от российских вкладчиков. Например, они вправе вносить предложения по вопросам управления деятельностью партнерства, обращаться с иском в суд в отношении ответственного участника при нанесении ущерба партнерству, требовать реализации своих прав и обращаться в суд от имени предприятия при невозможности реализации прав управляющим участником.

Решения в партнерствах принимаются большинством голосов. Также действует принцип «один участник - один голос». Однако закон устанавливает ряд вопросов, по которым решения должны приниматься только при единогласном одобрении. К ним относятся: изменение наименования партнерства, изменение сферы деятельности, места ведения хозяйственной деятельности, распоряжение недвижимым имуществом партнерства, передача или распоряжение имущественными правами, предоставление обеспечения иным лицам от имени партнерства, прием на должность руководителя партнерства лиц, не являющихся участниками партнерства (ст. 31 Закона 1997 г.).

При передаче участником своей доли другому лицу необходимо согласие всех участников, более того, они обладают правом преимущественной покупки доли одного из участников. Равным образом при вступлении в общее партнерство нового партнера необходимо единогласное одобрение всеми партнерами и заключение письменного соглашения о вступлении в партнерство, если учредительным договором отдельно не установлено иное. В этом случае, прежние партнеры должны достоверно информировать нового партнера о хозяйственном и финансовом состоянии партнерства (ст. 43 Закона КНР 1997 г.).

Закон КНР 1997 г. также содержит положение о передачи доли участником партнерства в залог. На совершение подобной сделки необходимо получить единогласное согласие всех участников, а при отсутствии последнего сделка считается недействительной.

Необходимо отметить, что Закон КНР жестко постановил, что занятие участниками обычного партнерства конкурентной предпринимательской деятельностью запрещено. Что касается обращения взыскания на долю участника в партнерстве, кредиторы вправе в соответствии с установленной процедурой обратиться в суд для погашения в принудительном порядке обязательств участника партнерства. Участник, выбывший из партнерства, несет неограниченную ответственность по обязательствам партнерства, возникшим до момента его выбытия (ст. 53 Закона 1997 г.).

В целом, основные обозначенные вопросы, касающиеся правового регулирования деятельности партнерства с ограниченной ответственностью, в КНР схожи с регулированием деятельности общего партнерства за исключениями, некоторые из которых будут отмечены ниже.

Важно подчеркнуть, что Закон КНР 1997 г. четко устанавливает количество участников в партнерствах с ограниченной ответственностью, - от 2 до 50 , а также наличие как минимум одного обычного участника. В качестве вклада участники с ограниченной ответственностью не могут внести трудовые услуги, поскольку данная категория участников не осуществляет ведение дел партнерства. В связи с тем, что управление делами партнерства осуществляют обычные участники, последние вправе требовать вознаграждение за свою работу и закрепить в учредительном договоре соответствующее положение.

Кроме того, участники с ограниченной ответственностью вправе знакомиться с финансовыми и бухгалтерскими книгами, а также, что немаловажно, участвовать «в принятии решений о вступлении в партнерство и выходе обычных участников; выносить предложения по вопросам управления деятельностью партнерства; требовать реализации прав или обращение с иском в суд в отношении ответственного участника при нанесении ущерба интересам ограниченного партнерства; требовать реализации своих прав или обращения с иском в суд от имени предприятия при невозможности реализации прав управляющим участником; предоставлять залог партнерству» (ст. 68 Закона 1997 г.). Кроме того, «участники с ограниченной ответственностью могут самостоятельно или в сотрудничестве с иными лицами вести деятельность, составляющую конкуренцию с деятельностью ограниченного партнерства; однако если учредительным договором отдельно не установлено иное» (ст. 71 Закона 1997 г.).

Помимо вышеприведенных сведений в учредительный договор партнерства с ограниченной ответ- 
ственностью необходимо внести: имена и фамилии (наименования), место проживания (нахождения) участников, отвечающих неограниченно, и участников с ограниченной ответственностью; требования к управляющим участникам и порядок их выбора; объем полномочий управляющих и способы разбирательства в случае нарушения ими условий договора; условия исключения из числа управляющих участников и порядок их замены; порядок изменения статуса обычных участников и участников с ограниченной ответственностью (ст. 53 Закона 1997 г.).

Ликвидация партнерств также регламентируется Законом КНР о партнерствах 1997 г. Решение о ликвидации и роспуске партнерства принимается всеми его участниками. Ликвидация может осуществляться добровольно и принудительно. Процедура ликвидации также начинается с назначения ликвидаторов партнерства по решению всех его участников. Кроме того, допускается назначение на должности ликвидаторов одного или нескольких участников при одобрении большинства участников. В ином случае назначается третье лицо в течение 15 дней после возникновения причины для роспуска партнерства. Если же в этот срок ликвидатор не назначается, участники партнерства вправе обратиться с заявлением в народный суд о назначении ликвидаторов. Основные полномочия ликвидаторов заключаются в составлении описи имущества и баланса, выявлении и удовлетворении требований кредиторов, погашении налоговой и получении дебиторской задолженностей. Для этого ликвидаторы в течение 10 дней после назначения должны уведомить всех кредиторов о ликвидации, а также в течение 60 дней опубликовать официальное заявление. Кредиторы в течение 30 дней со дня получения уведомления должны обратиться к ликвидаторам, обосновав свои требовании предоставленными соответствующие документы. Далее ликвидаторы регистрируют требование кредитора. Имущество партнерства, оставшееся после удовлетворения требований кредиторов и покрытия расходов социального страхования, по выплате заработной платы рабочим и связанных с проведением ликвидации, распределяются между его участниками. После завершения всех расчетов, ликвидаторы составляют отчет и в течение 15 дней уведомляют регистрирующий орган о снятии партнерства с регистрационного учета (ст. 90 Закона 1997 г.).

В Юж⿻е-Африканской Республике правовое регулирование деятельности партнерств осуществляется на основе общего (прецедентного) права [20]. Отдельного законодательного акта, регулирующего правовой статус партнерств, не существует. Подход к определению понятия партнерства, как нам удалось выявить в ходе исследования, в целом не отличается от рассмотренных нами стран. Так, под партнерством (partnership) понимается объединение лиц, участники которого в соответствии с заключенным между ними договором, занимаются предпринимательской деятельностью от имени партнерства, при этом количество участников партнерства четко определено: от двух до двадцати участников. Партнерства не являются юридическими лицами и не подлежат занесению в Государственный реестр.

Существуют следующие виды партнерств: общее (генеральное - general partnership) и коммандитное (commanditarian partnership) [21]. Необходимо отметить, что правовая система ЮАР имеет, как нами уже отмечалось выше, смешанный характер, сочетающий элементы римско-голландского и английского права [22, с. 924]. В связи с этим праву ЮАР известен также такой вид партнерства, как негласное партнерство (anonymous/sleeping partnership).

В генеральном партнерстве в ЮАР, как и в других рассмотренных выше странах, каждый участник партнерства несет солидарную и субсидиарную ответственность по обязательствам партнерства всем своим имуществом. Участники вкладывают свой личный труд в деятельность партнерства и осуществляют непосредственное управление. В качестве вклада в капитал партнерства могут выступать деньги, имущество и личные навыки. Прибыль распределяется в соответствии с заключенным договором между участниками пропорционально внесенным вкладам [20]. В случае смерти, выбытия или объявления партнера неплатежеспособным партнерство подлежит ликвидации.

Что касается коммандитного партнерства, правовое регулирование в ЮАР опять-таки практически не отличается от других государств. Характерным признаком такого партнерства является наличие двух видов участников: участников, отвечающих по долгам товарищества неограниченно и солидарно, и коммандитистов - вкладчиков, которые несут ответственность лишь в пределах суммы внесенного вклада. Коммандитисты не участвуют в управлении товариществом, лишь имеют право на получение соответствующей прибыли.

Негласное партнерство, так же, как и в праве Бразилии, предполагает наличие, помимо обычных участников, негласного (silent) партнера. Негласный партнер, в соответствии с заключенным договором с партнерством, обязан внести предусмотренный капитал. Ответственность его поэтому ограничена пределами суммы вклада. Управление таким партнерством осуществляется собственником предприятия, 
и для третьих лиц негласный партнер не существует. Таким образом, негласный партнер скрыт от внешнего мира, а бизнес ведут другие партнеры от собственного имени [23, p. 60]. Система управления в партнерствах ЮАР достаточно проста, поскольку партнерства не наделяются статусом юридического лица и не подлежат регистрации. Право ЮАР придерживается принципа участия в управлении участников с неограниченной ответственностью и наделения их солидарной ответственностью [20]. Участники с ограниченной ответственностью никакого участия в управлении не принимают. Они лишь вправе знакомиться со всей документацией о деятельности партнерства.

В случае прекращения деятельности партнерства его активы ликвидируются, кредиторам выплачиваются долги, и партнеры отвечают по долгам в недостающей от ликвидации активов части [20].

Обращение к сравнительному методу исследования позволило выявить общие для стран БРИКС подходы, касающиеся содержательного наполнения трактовки понятия «товарищество (партнерство)» и некоторые особенности.

1. Установлено, что право всех стран БРИКС определяет полное товарищество (генеральное партнерство / партнерство с неограниченной ответственностью - general partnership) как объединение лиц, участники которого несут неограниченную ответственность по обязательствам товарищества (партнерства), а коммандитное товарищество (партнерство с ограниченной ответственностью limited liability partnership - Индия, commanditarian partnership - ЮАР) - как объединение двух видов участников: с ограниченной и с неограниченной ответственностью, последние из которых осуществляют управление делами такого объединения. То есть, несмотря на приверженность законодательства стран БРИКС разным правовым системам в них наблюдается обусловленная единством целей правового регулирования унификация правовых конструкций, заключающаяся в схожести определения и содержательного наполнения понятий и признаков договорных объединений - полного / общего, обычного (general / common) товарищества / партнерства (partnership) и коммандитного (commanditarian) / с ограниченной ответственностью (limited liability) товарищества / партнерства (partnership).
2. Выявлено, что унифицированными признаками договорных объединений являются:

- наличие учредительного договора, включающего в себя требуемые законодательством положения о правовой основе деятельности товарищества (партнерства), составе его участников, их правах, обязанностях и ответственности, порядке управления товариществом (партнерством), его ликвидации и т.д.;

- действие правового принципа, закрепляющего в законах этих стран равенство таких прав участников товарищества (партнерства), как право каждого участника на получение информации о деятельности товарищества (партнерства); право каждого участника с неограниченной ответственностью на управление делами товарищества (партнерства) и т.д.;

- нормативно-явочный способ создания (исключительно по воле учредителей) при контролирующей функции государства относительно соблюдения требований законодательства.

3. Показано, что страны БРИКС можно разделить на те, в которых хозяйственные товарищества признаются после государственной регистрации юридическими лицами (Бразилия, Россия) и на те, в которых за хозяйственными товариществами статус юридического лица не закрепляется (Китай, ЮАР). В Индии партнерство с неограниченной ответственностью не является юридическим лицом, но подлежит государственной регистрации, а партнерство с ограниченной ответственностью - признается юридическим лицом и должно быть зарегистрировано соответствующим образом.

4. Выявленные отличия касаются, в основном, полных товариществ и заключаются в регламентации прав и ответственности участников. Так, например, в Бразилии участниками полного товарищества (юридического лица) вправе быть только физические лица; в России полные товарищи (физические и юридические лица), выбывшие из товарищества (юридического лица), несут ответственность по долгам товарищества в течение 2 лет после выбытия; в Индии участники общего партнерства вправе заниматься иной предпринимательской деятельностью (при условии выплаты партнерству всей полученной от нее прибыли); в ЮАР количество участников партнерства ограничено числом от 2 до 20 .

\section{Библиография:}

1. Lei No 10.406, de 10 de Janeiro de 2002. Institui o Código Civil. URL: http://www.planalto.gov.br/ccivil_03/leis/2002/110406. htm (дата обращения: 31.03.2016)

2. Смешанные виды торговых товариществ в континентальной системе права // Гражданское и торговое право зарубежных государств. Т. І / Отв. ред. Васильев Е.А., Комаров А.С. М.: Междунар. отношения, 2008. С. $258,259$. 
3. Беликова К.М. Правовое регулирование торгового оборота и кодификация частного права в странах Латинской Америки. М.: Юстицинформ, 2010. С. 280-281.

4. Brazil Company Formation. URL: http://startupbrazil.co.uk/company-formation/ (дата обращения: 03.09.2013)

5. Danilo Nogueira. The Law of Business Organizations under the New Brazilian Civil Code. URL: http://www.bokorlang.com/ journal/27brascorp.htm (дата обращения: 31.03.2016)

6. Часть первая Гражданского кодекса Российской Федерации от 30 ноября 1994 г. N 51-Ф3 // СЗ РФ от 5 декабря 1994 г. № 32 ст. 3301.

7. Беликова К.М. Основы гражданского права. // Правовое обеспечение профессиональной деятельности: учебное пособие для бакалавров / Под ред. проф. А.Я. Капустин. 2-е изд., перераб. и доп. М.: Юрайт, 2013. С. 54 (Серия: Бакалавр. Базовый курс).

8. Гражданское право. В 4 т. Т. 1: Общая часть. / Отв. ред. Е.А. Суханов. М.: Волтерс Клувер, 2010. С. 145-175.

9. Щеглова К.Д. Правовое положение участников товарищества на вере // Известия Российского государственного педагогического университета им. А.И. Герцена. 2007. № 45. С. 300-302.

10. Мельникова Т.В. К вопросу о правовом статусе полного товарищества (на примере сравнительного анализа российского и североамериканского права) // Юрист. 2013. № 7 // Информационный банк «Консультант+» “Юридическая пресca". URL: http://base.consultant.ru/cons/cgi/online.cgi?req=doc;base=CJI;n=70130 (дата обращения: 31.03.2016)

11. The Indian Partnership Act No. IX of 1932. URL: http://www.mca.gov.in/Ministry/actsbills/pdf/Partnership_Act_1932.pdf (дата обращения: 31.03.2016)

12. The Limited Liability Partnership Act, 2009. URL: http://www.mca.gov.in/MinistryV2/1lpact.html (дата обращения: 31.03.2016)

13. Partnerships in India Leverage Strengths for Success. October 2009. URL: http://wwwl.ifc.org/wps/wcm/connect/78a73c00 48a7e52ca09fe76060ad5911/IFC_India_LL_Brochure_20.pdf?MOD=AJPERES (дата обращения: 31.03.2016)

14. Procedure for Registration of a Partnership Firm. URL: http://business.gov.in/starting_business/partnership.php (дата обращения: 25.02.2013)

15. Беликова К.М. Агентские правоотношения в Англии // Торговое представительство и посредничество в праве Европейского Союза: сходные черты и различия в нормах о представительстве и посредничестве в странах с разносистемными правопорядкам // Законодательство. 2012. № 5. С. 67-76.

16. Гражданское и торговое право зарубежных стран / Под общ. ред. В.В. Безбаха и В.К. Пучинского. М.: МЦФЭР, 2004. C. 214.

17. Kumar R., Saha L. The Concept of Liquidation/Winding up in India. URL: http://www.chasecambria.com/site/journal/article. php?id=64 (дата обращения: 31.03 .2016 )

18. Partnership Enterprise Law of the People's Republic of China, February 23, 1997 (as Amended on August 27, 2006) // URL: http://www.fdi.gov.cn/pub/FDI_EN/Laws/GeneralLawsandRegulations/BasicLaws/P020061018643910006967.pdf(дата обращения: 31.03.2016)

19. Paul McKenzie, Fraser Mendel. China’s Partnership Enterprise Law Revised. URL: http://www.chinalawandpractice.com/ Article/1690319/Channel/9943/Chinas-Partnership-Enterprise-Law-Revised.html (дата обращения: 31.03.2016)

20. A Partnership as a legal entity. URL: http://southafrica.smetoolkit.org/sa/en/content/en/5244/A-Partnership-as-a-legal-entity (дата обращения: 31.03.2016).

21. Forms of Business in South Africa. URL: http://www.jumpstarthandbook.co.za/HandbookPdfs/5c.pdf (дата обращения: 31.03.2016).

22. Сухарев А.Я. Правовые системы стран мира. Энциклопедический справочник. 3-е изд., перераб. и доп. / Отв. ред. докт. юрид. наук, проф. А.Я. Сухарев. М: Издательство HOPMA, 2003. С. 924. URL: http://www.pravo.vuzlib.su/ book_z1290_page_159.html (дата обращения: 19.03.2016)

23. Briscoe A. Review of business laws in Southern Africa: report prepared for the SEPAC Working group "Policy Issues". [Electronic ed.]. Gaborone, 1999. P. 60.

\section{References (transliterated):}

1. Belikova K.M. Pravovoe regulirovanie torgovogo oborota i kodifikatsiya chastnogo prava v stranakh Latinskoi Ameriki. M.: Yustitsinform, 2010. S. 280-281.

2. Danilo Nogueira. The Law of Business Organizations under the New Brazilian Civil Code. URL: http://www.bokorlang.com/ journal/27brascorp.htm (data obrashcheniya: 31.03.2016)

3. Belikova K.M. Osnovy grazhdanskogo prava. // Pravovoe obespechenie professional'noi deyatel'nosti: uchebnoe posobie dlya bakalavrov / Pod red. prof. A.Ya. Kapustin. 2-e izd., pererab. i dop. M.: Yurait, 2013. S. 54 (Seriya: Bakalavr. Bazovyi kurs).

4. Shcheglova K.D. Pravovoe polozhenie uchastnikov tovarishchestva na vere // Izvestiya Rossiiskogo gosudarstvennogo pedagogicheskogo universiteta im. A.I. Gertsena. 2007. № 45. C. 300-302.

5. Mel'nikova T.V. K voprosu o pravovom statuse polnogo tovarishchestva (na primere sravnitel'nogo analiza rossiiskogo i severoamerikanskogo prava) // Yurist. 2013. № 7 // Informatsionnyi bank «Konsul’tant+»" "Yuridicheskaya pressa". URL: http://base.consultant.ru/cons/cgi/online.cgi?req=doc;base=CJI;n=70130 (data obrashcheniya: 31.03.2016)

6. Belikova K.M. Agentskie pravootnosheniya v Anglii // Torgovoe predstavitel'stvo i posrednichestvo v prave Evropeiskogo Soyuza: skhodnye cherty i razlichiya v normakh o predstavitel'stve i posrednichestve v stranakh s raznosistemnymi pravoporyadkam // Zakonodatel'stvo. 2012. № 5. S. 67-76. 
DOI: $10.7256 / 1811-9018.2016 .4 .18567$

При цитировании этой статьи сноска на doi обязательна

Интеграционное право и наднациональные организации

7. Kumar R., Saha L. The Concept of Liquidation/Winding up in India. URL: http://www.chasecambria.com/site/journal/article. php?id=64 (data obrashcheniya: 31.03 .2016 )

8. Paul McKenzie, Fraser Mendel. China's Partnership Enterprise Law Revised. URL: http://www.chinalawandpractice.com/ Article/1690319/Channel/9943/Chinas-Partnership-Enterprise-Law-Revised.html (data obrashcheniya: 31.03.2016)

9. Sukharev A.Ya. Pravovye sistemy stran mira. Entsiklopedicheskii spravochnik. 3-e izd., pererab. i dop. / Otv. red. dokt. yurid. nauk, prof. A.Ya. Sukharev. M: Izdatel'stvo NORMA, 2003. S. 924. URL: http://www.pravo.vuzlib.su/book_z1290_page_159. html (data obrashcheniya: 19.03.2016)

10. Briscoe A. Review of business laws in Southern Africa: report prepared for the SEPAC Working group "Policy Issues". [Electronic ed.]. Gaborone, 1999. P. 60. 